\title{
Performance of Finnsheep in South Africa
}

\author{
J C GreefF, J H Hofmeyr, D J Lourens, G A Wyma and K Majala
}

Greeff, J.C., Hofmeyr, J.H., Lourens, D.J., Wyma, G.A. \& MaUAla, K. 1992. Performance of Finnsheep in South Africa. Agric. Sci. Finl. 1: 195-202. (Irene Anim. Breed., SF-31600 Jokioinen, Finland.)

Reproduction, survival, growth and wool parameters were calculated for an experimental flock of Finnsheep from 1969 until 1986 under semi-intensive conditions. The total number of lambs born were 1774. Litter size, survival rate at birth and from birth to weaning differed significantly $(\mathrm{P}<0.01)$ between years. Lambing percentages varied between 56.0 and $90.6 \%$ while average litter size varied between 1.97 and 3.1 lambs. Survival rate at birth declined as litter size increased, from $92.2 \%$ for singletons to $63.5 \%$ for quintuplets, while survival rate from birth to weaning also declined from $74.1 \%$ for singletons to $57.0 \%$ for quintuplets. For singletons, twins, triplets, quadruplets and quintuplets the least squares means of birth mass was $2.5 \pm 0.06 ; 2.2$ $\pm 0.05 ; 2.0 \pm 0.05 ; 1.8 \pm 0.06$ and $1.7 \pm 0.10$, weaning mass was $19.0 \pm 0.47 ; 16.8 \pm$ $0.37 ; 16.8 \pm 0.36 ; 16.2 \pm 0.45$ and $16.4 \pm 0.94$, and 12 months mass $43.9 \pm 1.5 ; 40.1$ $\pm 1.4 ; 38.5 \pm 1.3 ; 37.0 \pm 1.5$ and $38.9 \pm 4.7$ respectively. Average fleece mass were 2.6 and $2.4 \mathrm{~kg}$ with an average fibre diameter of 26.0 and 26.7 micron for rams and ewes, respectively.

Key words: Finnsheep, ewe reproduction, lamb survival, lamb growth, wool

\section{Introduction}

Attempts to improve economic and biological efficiency in sheep production systems have focussed attention on the vital role of reproduction and consequently on highly fertile sheep breeds of the world. Improvement in the reproduction rate through accelerated lambing and/or higher fecundity of the ewe flock may offer the greatest opportunity for increasing production. The infusion of high fertility genes through crossbreeding has proved to be the most rapid breeding procedure to increase the reproduction rate in sheep flocks and the Finnish Landrace has been used extensively for this purpose (MaJala, 1984). However, with the exception of a few publications (eg. Goot et al., 1979; Majuala and Österberg 1977; Majala 1984; ABOUl-NAGa 1988; BAKER 1988; BoYlan et al. 1988; VALls OrTIZ 1988) there appears to be comparatively little published information on the general performance of Finnsheep. A nucleus of Finnish Landrace sheep (Finnsheep) was 
imported into South Africa during 1968 for experimental purposes. The original consignment consisted of 5 rams and 20 ewes. A subsequent importation of semen from four rams was made in 1981 . This paper reports on the performance of this nuclues flock of pure bred Finnsheep over a 18 year period in a temperate environment in South Africa.

\section{Material and methods}

\section{Experimental animals and general management}

The animals were kept at the Animal and Dairy Science Research Institute (ADSRI), latitude 22 55 ", longitude 2812 ", and altitude $1523 \mathrm{~m}$ above sea level. The climate is representative of the main inland region, with hot summer days and cool nights while the winter days are moderate with cold nights (sub-zero during June-August). The average rainfall is $580 \mathrm{~mm}$ per year which occurs mainly in summer (November-March).

After importation the animals were kept under confined veterinary quarantine conditions for three and a half years and standard management practices were followed with one lambing per year. Handmating was practised and mating took place during April and May (Autumn) each year with lambing during September and October (Spring). Three to four days before lambing ewes were penned individually where they lambed under close supervision and where birth details were recorded. Depending on the milk flow of the ewe, lambs were reared by their dams or received additional cow's colostrum for approximately 3 days after birth. Thereafter, depending on litter size and the strength of the lambs, they received additional cow's milk until weaning.

Initially, the animals received a basic diet of milled lucerne hay ad libitum with a daily allowance of about $200 \mathrm{~g}$ of a commercially pelleted concentrate. As from 1978 the animals were kept on Pennisetum clandestinum pastures and received a complete pelleted diet during late pregnancy and lactation. From three weeks of age the lambs had free access to the complete pelleted diet and received this diet through weaning at about 100 days of age until about six months of age. Ewe lambs mated at seven months of age were kept on this diet until their lambs were weaned.

\section{Statistical methods}

Lambing percentage and survival rate were analysed with a Chi-square procedure (STEEL and TORRIE, 1980) while fecundity, growth and wool data were analysed with the least squares means and maximum likelihood computor programme of HARVEY (1977). Year of birth, type of birth (i.e. singles or multiples), age of dam and sex of lamb were included in the model as fixed effects. Contrasts were used to test for significant differences between effects within a major class.

\section{Results}

\section{Reproductive performance and survival}

Observations on lambing percentage, fecundity and mortality rate for the flock are indicated in Table 1.

Year had a significant effect $(\mathrm{P}<0.01)$ on lambing percentage, fecundity and survival rate. Compared to the results of MAJJALA and ÖSTERBERG (1977), the lambing percentage was lower because ewe lambs which were mated at 7 months of age were included in the analyses. Ewes that were mated for the first time at about 7 months of age had an average lambing percentage of $56.8 \%$. This low lambing percentage is probably due to a low body mass of less than $27 \mathrm{~kg}$ at time of mating. In 1977 ewe lambs were not mated at 7 months of age which accounted for the $100 \%$ lambing percentage recorded for the subsequent breeding season. In 1983 all ewes were artificially inseminated with imported frozen Finnsheep semen which accounted for the $23.4 \%$ lambing percentage. In 1984, 1985 and 1986 mature ewes were intra-uterally inseminated, after which ewes that did not conceive were mated to Finn rams. An average fecundity of $239.4 \%$ was obtained with a range of $197.6 \%(1978)$ to $310 \%$ 
Table 1. Lambing percentage, fecundity and mortality rate of Finnsheep from 1969 until 1986.

\begin{tabular}{|c|c|c|c|c|c|c|}
\hline \multirow[b]{2}{*}{ Year } & \multirow[b]{2}{*}{ Lambing } & \multirow[b]{2}{*}{ Fecundity } & \multirow[b]{2}{*}{$\begin{array}{l}\text { Number } \\
\text { of } \\
\text { lambs } \\
\text { born }\end{array}$} & \multicolumn{3}{|c|}{ Mortality } \\
\hline & & & & $\begin{array}{l}\text { at } \\
\text { birth } \\
\text { (\%) }\end{array}$ & $\begin{array}{l}\text { from } \\
\text { birth } \\
\text { to } \\
\text { weaning } \\
(\%)\end{array}$ & $\begin{array}{l}\text { from } \\
\text { weaning } \\
\text { to } 12 \\
\text { months } \\
(\%)\end{array}$ \\
\hline 1969 & - & 221.4 & 31 & 10 & 21 & - \\
\hline 1970 & - & 213.3 & 32 & 25 & 17 & - \\
\hline 1971 & - & 230.8 & 60 & 23 & 37 & 31 \\
\hline 1972 & - & 220.0 & 77 & 25 & 50 & 0 \\
\hline 1973 & 87.8 & 230.0 & 115 & 25 & 41 & - \\
\hline 1974 & - & 227.8 & 82 & - & - & 52 \\
\hline 1975 & - & 262.3 & 202 & 14 & 31 & 91 \\
\hline 1976 & 83.3 & 227.2 & 184 & 20 & 40 & 24 \\
\hline $1977^{*}$ & 100.0 & 242.9 & 119 & 12 & 20 & 74 \\
\hline 1978 & 78.7 & 197.6 & 83 & 14 & 11 & 19 \\
\hline 1979 & 84.9 & 232.3 & 151 & 19 & 24 & 34 \\
\hline 1980 & 81.2 & 234.0 & 124 & 18 & 32 & 22 \\
\hline 1981 & 59.5 & 240.0 & 86 & 27 & 32 & 30 \\
\hline 1982 & 90.6 & 224.1 & 130 & 23 & 39 & 42 \\
\hline $1983^{* *}$ & 23.4 & 219.0 & 35 & 26 & 50 & 5 \\
\hline 1984 & 75.0 & 290.0 & 61 & 39 & 55 & 26 \\
\hline 1984 & 42.8(a) & 175.0 & 21 & 31 & 48 & 30 \\
\hline 1985 & 56.0 & 267.0 & 52 & 47 & 57 & 39 \\
\hline 1985 & $39.4(a)$ & 231.0 & 38 & 16 & 64 & 24 \\
\hline 1986 & 73.1 & 310.0 & 59 & 20 & 45 & 34 \\
\hline 1986 & 28.9(a) & 246.0 & 32 & 40 & 52 & 33 \\
\hline Average & $77.0(\mathrm{~b})$ & 239.4(b) & 1774 & 21 & 38 & 36 \\
\hline
\end{tabular}

Lambing percentage $=($ Number of ewes lambed $/$ ewes mated $) \times 100$

Fecundity $=($ Number of lambs born $/$ ewes lambed $) \times 100$

* During 1977 only ewes older than 12 months of age were mated,

** During 1983 all mature ewes were inseminated with frozen semen

(a) Lambing from intra-uterine inseminations

(b) Excluding 1977, 1983 and lambing from intra-uterine inseminations

Empty cells: Data not available

(1986) for handmating.

The age of the ewe had a significant effect $(\mathrm{P}<0.05)$ on fecundity which increased until 6 years of age (Table 2). The average mass of ewes at lambing was about $53 \mathrm{~kg}$. These fecundity rates agree very well with comparable results in the literature (MAiJAla and Österberg 1977). About $67 \%$ of all lambs were born either as twins or triplets while the rest were singles $(11 \%)$ quadruplets $(18 \%)$ or quintuplets $(5 \%)$ (Table 3$)$. Heavier ewes seem to produce more lambs (Table 3). Most of the lambs born as singles were from ewes lambing at 12 months of age.

In general the survival rate of lambs was very poor. Table 1 indicates an average mortality rate of $21 \%$ at birth, $38 \%$ from birth to weaning at 100 days and $36 \%$ from weaning until 12 months of age. During $197595 \%$ of all lambs born died before one year of age. It appears that there are two major causes of the high mortality rates among Finnsheep:

1. Environmental stress caused by diurnal fluctuations in temperature results in heavy losses in newborn lambs. 
Table 2. Average fecundity of Finnsheep per age group.

\begin{tabular}{lrll}
\hline $\begin{array}{l}\text { Age of the ewe } \\
\text { at lambing } \\
\text { (years) }\end{array}$ & $\mathrm{n}$ & $\begin{array}{l}\text { Average } \\
\text { body mass } \\
\text { at lambing } \\
(\mathrm{kg})\end{array}$ & $\begin{array}{l}\text { Fecundity } \\
(\%)\end{array}$ \\
\hline 1 & 81 & 43 & $161.7^{\mathrm{a}}$ \\
2 & 194 & 50 & $222.2^{\mathrm{b}}$ \\
3 & 151 & 56 & $232.2^{\mathrm{b}}$ \\
4 & 123 & 56 & $264.9^{\mathrm{c}}$ \\
5 & 84 & 56 & $260.0^{\mathrm{c}}$ \\
6 & 46 & 58 & $296.3^{\mathrm{d}}$ \\
7 & 27 & 58 & $233.9^{\mathrm{bc}}$ \\
8 & 12 & 52 & $255.2^{\text {bcd }}$ \\
9 & 5 & 47 & $261.9^{\text {bcd }}$ \\
& & & 243.1 \\
\hline
\end{tabular}

Means with different superscripts differ significantly $(\mathrm{P}<0.05)$

Table 3. Occurrence of multiple births of Finnsheep.

\begin{tabular}{lcc}
\hline Type of birth & $\begin{array}{l}\text { Average body } \\
\text { mass at } \\
\text { lambing (kg) }\end{array}$ & \% Occurrence \\
\hline Singletons & 51 & 11.1 \\
Twins & 52 & 33.9 \\
Triplets & 54 & 32.9 \\
Quadruplets & 55 & 17.6 \\
Quintuplets & 58 & 4.5 \\
\hline
\end{tabular}

Table 4. Survival rate at birth.

\begin{tabular}{lrccc}
\hline & & & \multicolumn{3}{c}{ Survival rate } \\
Type of birth & $\mathrm{n}$ & at birth & \multicolumn{2}{c}{$\mathrm{n}$ birth to weaning } \\
& & & $(\%)$ & $(\%)$ \\
\hline Singletons & 166 & $92.2^{\mathrm{a}}$ & 122 & $74.1^{\mathrm{a}}$ \\
Twins & 496 & $85.2^{\mathrm{b}}$ & 343 & $69.2^{\mathrm{ab}}$ \\
Triplets & 497 & $79.9^{\mathrm{c}}$ & 319 & $64.2^{\mathrm{bc}}$ \\
Quadruplets & 252 & $68.4^{\mathrm{d}}$ & 160 & $63.7^{\mathrm{bc}}$ \\
Quintuplets & 50 & $63.5^{\mathrm{d}}$ & 25 & $57.4^{\mathrm{c}}$ \\
\hline
\end{tabular}

Means in the same column with different superscripts differ significantly $(\mathrm{P}<0.05)$.
2. Finnsheep appear to be more susceptible than local breeds to lung diseases such as Pasteurellosis. Regular innoculation against this disease was not effective nor did sheep respond to treatment with antibiotics.

Survival rate is closely related to litter size (Table 4). As litter size increases, the survival rate at birth and from birth to weaning decreases significantly $(\mathrm{P}<0.05)$. Furthermore, notwithstanding the fact that lambs were fed additional milk irrespective of the type of birth, lambs born from ewes lambing at one year of age were generally weaker and required additional care.

\section{Gestation length}

No significant differences were found in gestation length between ewes with different litter sizes (Table 5), but these values (143 days) are lower than the average gestation length recorded for breeds such as the Merino (150.3 days), Karakul (150.7 days) and Romney Marsh (149.6 days) (Hugo, 1966).

\section{Breeding season}

Visscher (1974) reported that Finnsheep appears to have a longer breeding season than European breeds such as the Ile de France. To determine the oestrus pattern and the onset of oestrus of Finnsheep in South Africa, 26 ewe lambs born during October 1980 were teased with vasectomized rams for 12 months, from weaning at 100 days of age (January 1981) until December 1981 the same year. Ewes were teased daily and the number of ewes showing oestrus was recorded. The oestrus pattern of ewe lambs as a percentage of total oestrus response shown, is indicated in Table 6.

The first signs of oestrus occurred during March. In April there was a sharp increase which peaked in June. Thereafter it declined until October after which no signs of oestrus were recorded. Ewe lambs showed the first signs of oestrus at an average body mass of $31.8 \pm 3.98 \mathrm{~kg}$ and at $242 \pm 24.4$ days of age, with an oestrus every $16.1 \pm 1.03$ days on average. 
Table 5. Gestation length per type of birth (mean \pm standard deviation).

\begin{tabular}{lcc}
\hline Type of birth & $\begin{array}{c}\text { Number } \\
\text { births }\end{array}$ & $\begin{array}{c}\text { Gestation length (days) } \\
\overline{\mathrm{x}} \pm \mathrm{s} \mathrm{d}\end{array}$ \\
\hline Singletons & 39 & $143 \pm 2.44$ \\
Twins & 66 & $142 \pm 2.61$ \\
Triplets & 47 & $142 \pm 2.30$ \\
Quadruplets & 22 & $143 \pm 2.18$ \\
Quintuplets & 3 & $143 \pm 3.06$ \\
Total/Mean & 177 & 143 \\
\hline
\end{tabular}

Table 6. Seasonal oestrus pattern of Finnsheep ewe lambs $(\mathrm{n}=26)$.

Month $\quad \begin{gathered}\text { Oestrus as a percentage } \\ \text { of total oestrus shown }\end{gathered}$

\begin{tabular}{lr}
\hline February & - \\
March & 8.02 \\
April & 17.65 \\
May & 19.79 \\
June & 22.99 \\
July & 19.79 \\
August & 8.02 \\
September & 3.21 \\
October & 0.53 \\
November & - \\
\hline
\end{tabular}

\section{Body mass}

Table 7 indicates that as litter size increased, birth mass, weaning mass and 12 months mass decreased. No significant differences were found for wea- ning mass and 12 months mass between triplets, quintuplets and quadruplets, probably because quadruplets and quintuplets received preferential treatment from birth.

Age of the ewe had a highly significant effect $(\mathrm{P}<0.01)$ on birth mass and 12 months mass (Table 8 ) but not on weaning mass with a mean of $16.3 \mathrm{~kg}$, probably because the effect of milk production was eliminated, since weak lambs received additional milk from birth until weaning. As the age of the ewe increased, birth mass increased to an age of 9 years. The twelve month mass of lambs born from ewes lambing at about 1 year of age was significantly $\mathrm{P}<0.01$ ) lighter than lambs born from mature ewes, in spite of the fact that no significant differences were found for weaning mass.

Sex of the lamb also had a significant effect on birth mass, weaning mass and 12 months mass. In all cases ewe lambs were significantly $(\mathrm{P}<0.01)$ lighter than ram lambs (Table 9).

\section{Wool traits}

Table 10 indicates the wool characteristics of Finnsheep rams and ewes. Very light fleeces of respectively 2.6 and $2.2 \mathrm{~kg}$ were recorded for rams and ewes. However, no significant differences were found between rams and ewes for any wool trait. Visually the fleeces differ greatly from Merino type fleeces but with a fibre diameter of 26.0 and 26.7 micron, and with crimps per $25 \mathrm{~mm}$

Table 7. Least square means ( \pm SE) of birth mass, weaning mass and 12 months mass of Finnsheep according to type of birth.

\begin{tabular}{|c|c|c|c|c|c|}
\hline $\begin{array}{l}\text { Type of } \\
\text { birth }\end{array}$ & $\mathrm{n}$ & $\begin{array}{c}\text { Birth } \\
\text { mass } \\
\overline{\mathrm{x}} \pm \mathrm{SE} \\
(\mathrm{kg})\end{array}$ & $\begin{array}{l}\text { Weaning } \\
\text { mass } \\
\bar{x} \pm S E \\
(\mathrm{~kg})\end{array}$ & $\mathrm{n}$ & $\begin{array}{c}12 \text { months } \\
\text { mass } \\
\overline{\mathrm{x}} \pm \mathrm{SE} \\
(\mathrm{kg})\end{array}$ \\
\hline Singletons & 118 & $2.8 \pm 0.06 \mathrm{a}$ & $18.8 \pm 0.53 \mathrm{a}$ & 31 & $43.9 \pm 1.56 \mathrm{a}$ \\
\hline Twins & 342 & $2.5 \pm 0.06 \mathrm{~b}$ & $16.2 \pm 0.42 b$ & 69 & $40.1 \pm 1.35 b$ \\
\hline Triplets & 318 & $2.3 \pm 0.05 \mathrm{c}$ & $15.6 \pm 0.40 \mathrm{bc}$ & 65 & $38.5 \pm 1.31 b c$ \\
\hline Quadruplets & 160 & $2.1 \pm 0.06 \mathrm{~d}$ & $15.2 \pm 0.49 \mathrm{c}$ & 32 & $37.0 \pm 1.48 \mathrm{c}$ \\
\hline \multirow[t]{2}{*}{ Quintuplets } & 27 & $1.9 \pm 0.12 \mathrm{e}$ & $15.3 \pm 0.97 b c$ & 2 & $38.9 \pm 4.70 b c$ \\
\hline & 965 & & & 199 & \\
\hline
\end{tabular}

Means in the same column with different superscripts differ significantly $(\mathrm{P}<0.01)$ 
Table 8. Effect of age of the ewe on birth and 12 months mass.

\begin{tabular}{|c|c|c|c|c|}
\hline $\begin{array}{l}\text { Age of ewe } \\
\text { (years) }\end{array}$ & $\mathrm{n}$ & $\begin{array}{l}\text { L.S means of } \\
\text { birth mass } \\
\overline{\mathrm{x}} \pm \mathrm{SE}\end{array}$ & $\mathrm{n}$ & $\begin{array}{c}\text { L.S. means of } \\
12 \text { months mass } \\
\overline{\mathrm{x}} \pm \mathrm{SE}\end{array}$ \\
\hline 1 & 70 & $1.89 \pm 0.08^{\mathrm{a}}$ & 8 & $34.7 \pm 2.66^{\mathrm{a}}$ \\
\hline 2 & 237 & $2.05 \pm 0.05^{\mathrm{a}}$ & 39 & $38.8 \pm 1.61^{b}$ \\
\hline 3 & 232 & $2.20 \pm 0.05^{b}$ & 59 & $37.9 \pm 1.49^{b}$ \\
\hline 4 & 181 & $2.25 \pm 0.05^{b}$ & 46 & $40.2 \pm 1.62^{b}$ \\
\hline 5 & 115 & $2.26 \pm 0.06^{\mathrm{b}}$ & 26 & $38.3 \pm 1.74^{b}$ \\
\hline 6 & 67 & $2.33 \pm 0.07^{\mathrm{bd}}$ & 12 & $46.8 \pm 2.35^{c}$ \\
\hline 7 & 44 & $2.33 \pm 0.09^{\mathrm{bd}}$ & 8 & $39.9 \pm 2.45^{b}$ \\
\hline 8 & 15 & $2.63 \pm 0.15^{\mathrm{c}}$ & 1 & $41.1 \pm 0.00^{b}$ \\
\hline 9 & 4 & $2.77 \pm 0.28^{\mathrm{cd}}$ & - & - \\
\hline
\end{tabular}

Means in the same column with different superscripts differ significantly $(\mathrm{P}<0.01)$

Table 9. Least square means ( \pm SE) of birth mass, weaning mass and 12 months mass of ram and ewe lambs of Finnsheep.

\begin{tabular}{lrcrc}
\hline & $\mathrm{n}$ & Ram lambs & & $\begin{array}{c}\text { Ewe lambs } \\
\overline{\mathrm{x}} \pm \mathrm{SE}\end{array}$ \\
\hline Birth mass $(\mathrm{kg}$ & 486 & $\mathrm{n}$ & 479 & $2.22 \pm 0.05^{\mathrm{b}}$ \\
Weaning mass $(\mathrm{kg}$ & 486 & $2.38 \pm 0.05^{\mathrm{a}}$ & 479 & $15.5 \pm 0.42^{\mathrm{b}}$ \\
12 Months mass $(\mathrm{kg})$ & 92 & $17.0 \pm 0.40^{\mathrm{a}}$ & 107 & $37.6 \pm 1.50^{\mathrm{b}}$ \\
\hline
\end{tabular}

Means in the same row with different superscripts differ significantly $(\mathrm{P}<0.01)$

of 5.8 and 5.2 for rams and ewes respectively, Finnsheep wool falls within the acceptable Duerden standards (DUERDEN 1929).

\section{Carcass traits}

Thirteen ram and 16 ewe lambs were slaughtered at 5 different live masses. Each carcass was dissected into subcutaneous fat (scf), meat and bone and the mass of each component, as a percentage of the total carcass mass are indicated in Table 11.

Although a small number of lambs is involved, it is clear that as slaughter mass increases, dressing percentage and percentage subcutaneous fat in the carcass also increases while percentage bone decreases in accordance with the general tendency recorded in the literature (KEMPSTER et al., 1982). Ewe lambs had a higher dressing percentage and more subcutaneous fat than ram lambs at all masses while the percentage lean was about the same. It
Table 10. Least squares means of wool traits of Finnsheep.

\begin{tabular}{lrr}
\hline Trait & Rams & Ewes \\
& $\overline{\mathrm{x}}$ & $\overline{\mathrm{x}}$ \\
\hline Number of animals & 364 & 790 \\
Greasy fleece mass (kg) & 2.6 & 2.2 \\
Fibre diameter (micron) & 26.0 & 26.7 \\
Staple length (mm) & 110.2 & 105.5 \\
Crimps per 25mm & 5.8 & 5.2 \\
Clean yield (\%) & 63.8 & 66.8 \\
Fibre deviation from & & \\
Duerden standard (= 100) & 101.0 & 98.0 \\
\hline
\end{tabular}

appears that the amount of subcutaneous fat of both sexes is far less than the average amount of subcutaneous fat of 8.5 percent for carcasses of $17.5 \mathrm{~kg}$ of all sheep slaughtered in South Africa (BRUWER et al., 1987). These results agree with the findings of BoyLAN et al. (1976) in Finnsheep crosses, indicating the leanness of this breed. 
Table 11. Least squares means of carcass traits of Finnsheep lambs.

\begin{tabular}{|c|c|c|c|c|c|c|c|c|c|c|}
\hline \multirow[b]{2}{*}{$\begin{array}{l}\text { Slaughter } \\
\text { mass }(\mathrm{kg})\end{array}$} & \multicolumn{5}{|c|}{ Ram lambs } & \multicolumn{5}{|c|}{ Ewe lambs } \\
\hline & $\mathrm{n}$ & $\begin{array}{c}\text { Dressing } \\
(\%)\end{array}$ & $\begin{array}{l}\text { Scf } \\
(\%)\end{array}$ & $\begin{array}{l}\text { Meat } \\
(\%)\end{array}$ & $\begin{array}{l}\text { Bone } \\
(\%)\end{array}$ & $\mathrm{n}$ & $\begin{array}{c}\text { Dressing } \\
(\%)\end{array}$ & $\begin{array}{l}\text { Scf } \\
(\%)\end{array}$ & $\begin{array}{c}\text { Meat } \\
(\%)\end{array}$ & $\begin{array}{r}\text { Bone } \\
(\%)\end{array}$ \\
\hline 20 & 2 & 37 & 1.1 & 81.1 & 17.8 & 5 & 40 & 3.3 & 82.5 & 14.2 \\
\hline 25 & 3 & 41 & 2.6 & 83.0 & 14.4 & 3 & 44 & 4.7 & 81.4 & 13.9 \\
\hline 30 & 4 & 43 & 4.6 & 81.6 & 13.8 & 4 & 47 & 6.7 & 81.2 & 12.1 \\
\hline 35 & 3 & 44 & 5.7 & 81.1 & 13.2 & 3 & 47 & 7.4 & 79.5 & 13.1 \\
\hline 40 & 1 & 42 & 5.8 & 82.5 & 11.6 & 1 & 45 & 6.7 & 81.1 & 12.2 \\
\hline Total & 13 & & & & & 16 & & & & \\
\hline
\end{tabular}

Scf $=$ subcutaneous fat

\section{Conclusions}

With very few exceptions no significant role is seen for pure-bred Finnsheep in the local sheep industry. However, through crossbreeding, HOFMEYR (1980), GreEFF and HofmeYr (1988) and GreefF et al., (1990) showed that the high fertility of the Finnsheep can make a valuable contribution in increasing the reproductive efficiency of sheep production under intensive, semi-intensive and extensive conditions in South Africa.

Traditionally, the sheep industry has resisted any encouragement to promote multiple births in sheep. The comparatively low value of individual animals did not justify the managerial and labour inputs associated with multiple births such as the nursing and fostering of lambs. However, this perception has changed in recent years with the increase in improved pastures and relatively high mutton and lamb prices.

The local market has not been very receptive as far as Finnsheep wool is concerned, but HoFMEYR (1980) indicated that the processing qualities of Finn $x$ Merino wool was closer to Merino wool than that of any other Merino cross produced. As wool production is a major consideration in a country such as South Africa, the Finnsheep could play an important part in the establishment of a dual purpose white wool composite female line for the industry, especially where nutritional conditions favour intensive lamb production.

\section{References}

ABoul-NagA, A.M. 1988. Finnsheep and their crosses under subtropical conditions. J. Agric. Sci. Finl. 60: 473-480.

BAKER, R.L. 1988. Finnsheep and their utilization experiences in temperate conditions. J. Agric. Sci. Finl. 60: 455-472.

Boylan, W.J., Fecht, J.W. \& SaKul, H. 1988. Milk production in Finnsheep and Romanov breeds. J. Agric. Sci. Finl. 60: 603-607.

Boylan, W.J., Berger, Y.M. \& Allen, C.E. 1976. Carcass merit of Finnsheep crossbred lambs. J. Anim. Sci. 42: 1413-1420.

Bruwer, G.G., Naudé, R.T., Du Tort, M.M. \& Cloete, A. 1987. An evaluation of the lamb and mutton carcase grading system in the Republic of South Africa. 2. The use of fat measurements as predictors of carcase composition. S. Afr. J. Anim. Sci. 17: 85-89.

DUERDEN, J.E. 1929. Standards of thickness and crimps in Merino wools. J. Text. Inst. 20, 93 - 100.

Goot, H., Eyal, E., Folman, Y. \& Foote, W.C. 1979. Contemporary comparisons between progeny by Finnish Landrace and Romanov rams out of Mutton Merino and Awassi ewes. Livest. Prod. Sci. 6: 283-293.

GreefF, J.C. \& HofMEYR, J.H. 1988. Finnsheep and their utilization in crosses with the Merino under range conditions of South Africa. J. Agric. Sci. Finland. 60: 500 504.

—, Roux C.R. \& WYMA, G.A. 1990. Lifetime meat pro- 
duction from six different F. crossbred ewes. S. Afr. J. Anim. Sci. 20: 71 - 77.

HARVEY, W. 1977. User's guide for LSML76 Mixed model least-squares and maximum likelihood computer program. Ohio State Univ.

HOFMEYR, J.H. 1980. Implications of experimental results of crossbreeding sheep in the Republic of South Africa. Proc. World Congr. Sheep and Beef Cattle Breeding. Vol I. Ed. R A Barton and W C Smith. The Dunmore Press, New Zealand.

Hugo, W.J. 1966. Small stock industry of South Africa. Department of Agricultural Technical Services. Government Printer, Pretoria.

Kempster, A.J., Cuthbertson, A. \& Harrington, G. 1982. Carcase Evaluation in Livestock Breeding, Production and Marketing. Granada, London.

MauAla, K. 1984. Review of experiences about the use of Finnsheep in improving fertility. Proc. 2nd Wrld. Congr. Sheep Beef Cattle, Breed. held in Pretoria, p. 519-531.

— \& Österberg, S. 1977. Productivity of pure Finnsheep in Finnland and abroad. Livest. Prod. Sci. 4: 355-377.

STEEL, R.G.D. \& TORRIE, J.H. 1980. Principles and proce- dures of Statistics. McGraw-Hill.

VAlls OrTiZ, M. 1988. Finnsheep and Romanov comparative performances obtained under the same management conditions in Spain. J. Agric. Sci. Finland. 60: 553.

VISSCHER, A.H. 1974. A crossbreeding experiment with three breeds of sheep. Proc. Work. Symp. Breed Eval. Cross. Exp., Zeist: 475-491.

\section{Manuscript received September 1991}

\section{J C Greeff \\ J H Hofmeyr \\ D J Lourens}

G A Wyma

Irene Animal Production Institute

Irene 1675

Republic of South Africa

Kalle Maijala

Present address:

Haapatie 13 D

SF-00780 Helsinki, Finland

\title{
SELOSTUS
}

\section{Puhtaan suomenlampaan menestyminen Etelä-Afrikassa}

\author{
J C Greeff, J H Hofmeyr, D J Lourens, G A Wyma JA K Maijala \\ Irene Animal Production Institute ja Maatalouden tutkimuskeskus
}

Lammastalouden taloudellista ja biologista tehoa parannettaessa on kiinnitetty huomio lisääntymiskykyyn ja sikiäviin rotuihin. Sikiăvyysgeenien tuonti muista roduista on tässä osoittautunut nopeaksi menetelmäksi. Tähän on käytetty paljon suomenlammasta. Siitä haluttiin kokemuksia EteläAfrikassakin, jonne koe-eläinainesta tuotiin 1968 sekä lisăksi neljän pässin spermaa 1981. Nämä pidettiin sisämaassa (22 et.lev., 1523 m kork.), jossa kesăpäivăt ovat kuumia ja yöt viileitä, talvipäivăt lauhkeita ja yöt kylmiä. Sadetta tulee keskimäärin $580 \mathrm{~mm} / \mathrm{v}$., pääosa kesăllă.

Karitsointi-\%:ssa, vuonuekoossa ja eloonjäănti-\%:ssa oli merkitseviä vuosien välisiä eroja. Karitsointi-\% vaihteli $56.0-90.6 \%$ ja vuonuekoko 1.97 - 3.1. Eloonjäänti-\% syntyessä ja syntymästä vieroitukseen aleni vuonuekoon noustessa.

Syntymåvuosien ja -tyyppien välillä oli merkitseviä eroja syntymä-, vieroitus- ja $12 \mathrm{kk}$ :n painossa. Ykkösten vastaavat painot olivat 47,16 ja $13 \%$ suuremmat kuin viitosten, mutta 3-, 4- ja 5-karitsoiden văliset erot vieroitus- ja $12 \mathrm{kk}: \mathrm{n}$ painoissa eivät olleet merkitseviä, koska 4- ja 5-karitsat saivat lisähoitoa syntymästä alkaen. Uuhen iällä oli hyvin merkitsevă vaikutus syntymä- ja 12 kk:n painoon, mutta ei vieroituspainoon, koska heikkojen karitsoiden saama lisämaito syntymästä vieroitukseen eliminoi maidontuotannon vaikutuksen. Uuhen vanhetessa syntymäpaino nousi 9 vuoden ikäăn asti. 1-vuotisista uuhista syntyneet karitsat painoivat
12 kk:n iässä merkitsevăsti văhemmän kuin aikuisten uuhien karitsat, vaikka vieroituspainossa ei ollut merkitseviä eroja. Karitsoiden sukupuoli vaikutti merkitsevästi kaikkiin painoihin: uuhet olivat kevyempiä kuin păssit.

Sekä pässien että uuhien villamäärät olivat pienet (2.6, 2.2 $\mathrm{kg}$ ). Villan laadussa ei ollut merkitseviä sukupuolieroja. Se poikkesi suuresti merinotyypin villasta, mutta villakuitujen hienous ja kiharatiheys täyttivăt maan laatuvaatimukset.

Tulosten perusteella ei puhtaalle suomenlampaalle ole nähtåvisså merkittåvãă roolia Etelä-Afrikan lammastaloudessa. Risteytyskokeiden mukaan voidaan sen hyvăstä hedelmällisyydestä silti saada arvokas apu lammastalouden lisääntymistehoon maan erilaisissa voimaperäisyysolosuhteissa. Maassa on vastustettu monisynnytysten edistämistă, koska eläinyksilöiden văhăarvoisuus ei ole innostanut hoitotyön lisäämiseen. Käsitys on kuitenkin muuttunut viime vuosina, laitumien parantuessa sekä lampaanlihan hintojen noustessa. Maan villamarkkinat eivăt myöskään ole olleet kovin innostuneita suomenlampaan villasta, mutta suomenlammas x merinoristeytysten villan käsittelyominaisuudet ovat lähempänä merinovillaa kuin minkään muun rodun merino-risteytysten. Koska villa on maan lammastalouden päätuote, voisi suomenlammas näytellä tärkeätä osaa valkovilla-lihaemälinjan perustamisessa teollisuutta varten, erityisesti siellä, missä ruokintaolosuhteet suosivat voimaperäistă karitsantuotantoa. 